\title{
Importance of Social Media in Business Firm in Palestine \& its Effects
}

\author{
Nermeen Sayyad* \\ palestine
}

*Corresponding Author: Nermeen Sayyad, palestin

\begin{abstract}
Social media has provided new opportunities to businesses to engage customers through social interaction while creating leads and generating sales. No study has been conducted to identify the importance of social media and how social media has affected the marketing strategies of business firms in Palestine. 80 social media marketing experts were surveyed through a closed ended questionnaire in Palestine to find out the impact of social media on customer relationship building and sale volume of the businesses firms. Through regression and Pearson Correlation analysis, it is found that type of social media has insignificant correlation with social media for network building $(r=.010)$, to attract potential customers $(r=.003)$, and to engage customers $(r=.069)$, whereas it has significant positive correlation with social media to communicate with customers $(r=.104)$. Similarly, type of social media has a significantly positive correlation with the variables i.e. high sale $(r=.215)$ and high rate of return on investment $(r=.180)$.
\end{abstract}

\section{INTRODUCTION}

The advancement in the social media has provided companies and marketers a new channel for marketing, branding and promoting their products and services. An easy access to the internet has enabled the individuals or consumers the opportunity to use social media such as Twitter, Face book, and Instagram to interact and communicate with their favorite brands and companies without any physical interaction (Li, Zhou, Kashyap, \& Yang, 2008). Today, social media enables individuals to share and access the information and experience provided by other customers' information and recommendation (Liang, Ho, Li, \& Turban, 2011). Such information has a significant impact on the company's image and reputation. Therefore, businesses and companies have incorporated social media as an important part of their marketing plan (Naylor, Lamberton, \& West, 2012). In Palestine, the use of social media is widespread. The total population of Palestine is 6.75 million as of 2016, out of which 3.3 million people use internet whereas 2.4 million people use social media. Out of the total number of internet users, $84 \%$ users use Face book, $47 \%$ use WhatsApp, 18\%use Gplus, $16 \%$ Twitter, $16 \%$ use Instagram, and 6\% use LinkedIn (Patrick, 2008).

Similar to the common use of social media, social media is used in Palestine for various personal purposes including social networking, making connections with friends, customers and clients. In this regard, social media is being used in the country for both social and business purposes. A number of studies have researched the use of social media for the marketing purpose in various industries such as textile, foods and beverages manufacturers, hospitality and tourism, restaurant, and automotive industries that are actively using Facebook, Twitter and Instagram for publicizing and promoting products and services (Poynter, 2010). However, no study has focused on the impact and importance of social media on the business firms in terms of increased effectiveness of the marketing. According to Lu, Zhao, \& Wang (2010), social media offer various benefits to firms including increased brand identity, word of mouth publicity, and high sale volume. It is possible through sharing valuable information that aims to provide relevant information related to product or services while generating social support for customers. With the increasing popularity and use of social media by customers and businesses in Palestine, it has become significant to identify and determine the impact of social media on the business firms in the context of effective marketing channel in Palestine. Thus, the aim of the study is to identify how business firms in Palestine are using social media to transform their relationship with customers, and what effect social media is likely to have on the marketing activities 
of the firms such as brand identity, image and loyalty both from customers and employees' point of view.

\section{LiterATURE REVIEW AND THEORETICAL BACKGROUND}

With the advancement of the internet and wide use of social media, it has become easy for customers and businesses to interact often to collaborate in the business context. Besides personal networking through social media, there is widespread use of social media in the business. According to Fue, Li, \& Wenyu (2009), social media has enabled businesses to interact with the target audience by creating and sharing relevant information. Moreover, social media such as Facebook now provides review features to businesses to get the review based on the experience that is likely to affect the buying decision of potential customers. Thus, social media is empowering the customers to create and share content that is beneficial for other customers. Therefore, the effect of social media on the business firm is more than just a marketing channel. As asserted by Hanna, Rohm, \& Crittenden (2011), social media has revolutionized the traditional marketing tactics; however, it does not benefit every business in the same way. In this way, he determined that the social media affects the business firms and the effectiveness of their marketing activities largely depends on different factors such as type of the product, purchase and type social media platform. Aral, Dellarocas, \& Godes (2013) argued that regardless of product and purchase type if used correctly social media helps low, medium and high companies to boost their sales and create brand awareness.

Kim, Lim, \& Brymer (2015) while highlighting the benefits of social media by businesses indicated that social media has been helping marketers in building a relationship through likes, shares, comments and messages. Unlike traditional marketing where existing or potential consumers could not reach to the company to convey their experience. Thus, by getting direct feedback from customers, it is easy for businesses to improve their products and services that fulfil the customers' needs. In this effort to use social media for marketing, it is identified that social media has changed the way businesses and leaders were perceived. Qualman (2010) found that leaders also play an important role in creating the image of a business. For this purpose, it is suggested that businesses' leaders must embrace social media such as LinkedIn, Face book, and Twitter to create persona of a company outside the business. According to Kotler, Kartajaya, \& Setiawan (2016), social media provides twofold benefits to leaders; at first, social media is a free and easily accessible platform that can be used to a build personal brand. Secondly, leaders can represent the company by constantly engaging with the employees, customers, and other public while creating a brand image of the company. According to Scott (2017), today customers have become social paradox and they like to see how their favorite company or business reacts or responds to an event and show commitment to a purpose. Rao \& Raghavendra (2016), on the other hand, highlighted the negative impact of social media on the business firms. In this way, they highlighted that certain events can lead to the negative publicity of the company thereby impacting company's reputation. Jones, Borgman, \& Ulusoy (2015) pointed out the use of social media for the purpose of recruitment by the companies. They argued that social media is not only used for marketing brands but also used for creating a good image of a company. Using social media does not only help in recruitment but also can be used for showing a positive image of the company in front of potential customers. Kietzmann, Hermkens, McCarthy, \& Silvestre (2011) offered a framework that provides seven functional building blocks to define social media. These blocks include identity, conversation, sharing, presence, reputation, relationship and groups or community.

\section{CONCEPTUAl Model ANd Hypotheses}

Given that the aim of the study is to find the importance and effect of social media on business and firms, therefore, a conceptual framework is developed that is based on dependent and independent variables. Thus, social media is independent variable whereas its effect such as communicating with customers to build relationship and high sale are dependent variables.

Based on the above variables, two hypotheses are developed. In this way, null and alternative hypotheses will be developed that will help to determine which hypothesis is rejected or approved. The first hypothesis will try to find the way social media platforms are helping the business firms in Palestine to build strong relationship with customers. Thus, following hypothesis is developed: 


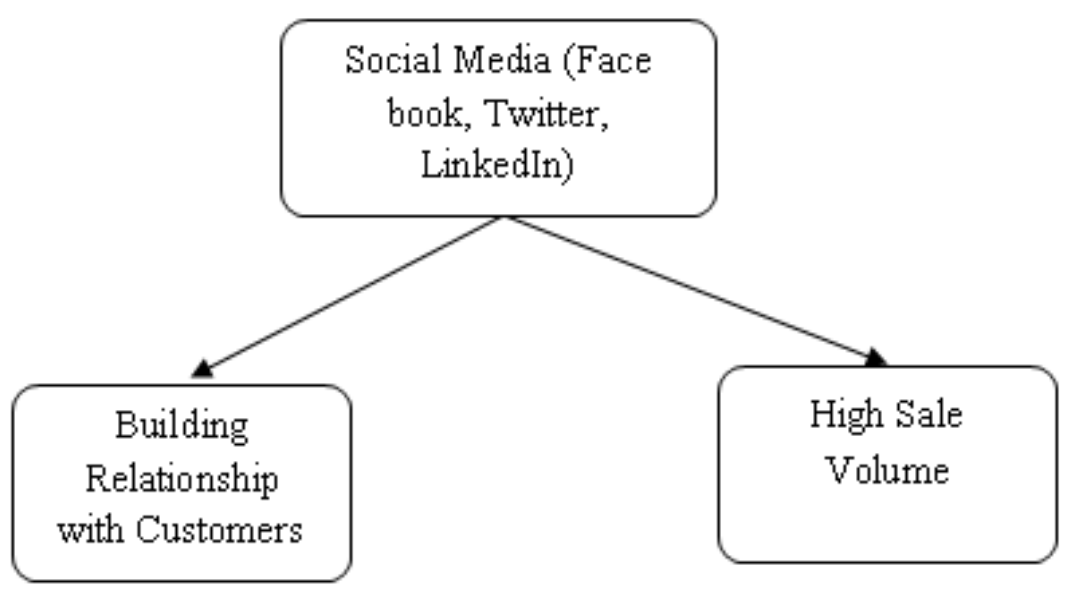

Figure1. Conceptual Model

$h_{0:}$ There is no relationship between uses of social media by business firms in Palestine and relationship building with customers.

$h_{1:}$ There is a positive relationship between uses of social media by business firms in Palestine and relationship building with customers.

$h_{0:}$ There is no relation between uses of social media by business firms in Palestine and high sales

$h_{2:}$ There is a positive relation between uses of social media by business firms in Palestine and high sales

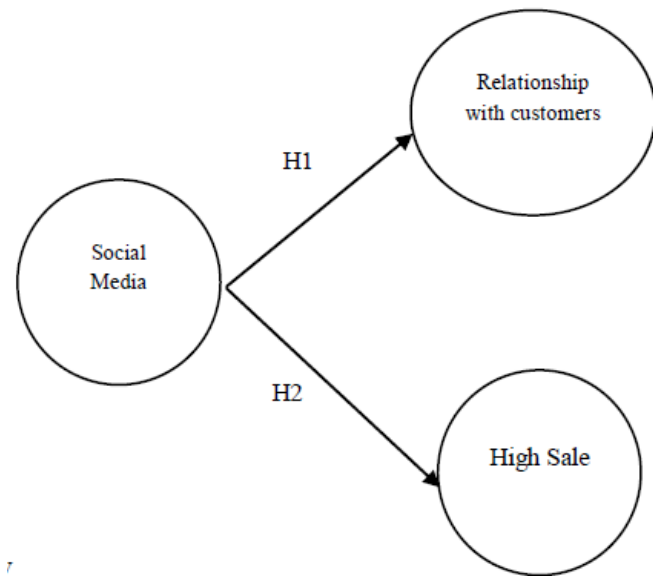

Figure1. Hypothesis Model

\section{RESEARCH METHODOLOGY}

In order to achieve the aim and objective and validate the proposed hypothesis, the author carried out a survey. The survey was conducted with 80 different Social Media Expert employed in different organizations of companies in Palestine through paper and online questionnaire.

\section{INSTRUMENT DEVELOPMENT}

A closed ended questionnaire was designed consisting of profile information and 13 questions by using a 5-point Likert-scale from $1=$ strongly disagree to $5=$ strongly agree. Questions were extracted from previous studies to enhance the validity and reliability of the study. Two independent variables of the study that are building customer relationship and high sale volume are studied in a number of previous studies. However, those studies have researched the phenomena from customers' point of view and no study has studied the phenomena from organizations' and marketers' point of view. Through this study, author has ensured to address the impact that social media has on the customer relationship and company's financial profitability from a different perspective. Thus, questions ask 
direct questions to the respondents concerning the impact they have observed as a result of using social media by the companies in Palestine.

\section{Data Collection}

100 questionnaires were distributed to Social Media Experts in Palestinian organizations randomly where 50 questionnaires were sent to the experts through Face book, Twitter, and Instagram profile and 100 were distributed in person. However, only 80 questionnaires were returned whereas respondents who were not Social Media Expert were excluded. Thus, out of 150 questionnaires only 80 questionnaires were useful for the study.

\section{RESEARCH METHOD}

In order to analyze the data, quantitative method is chosen i.e. regression and Pearson correlation coefficient analysis. Regression analysis will help in analyzing and identifying the causal relationships between the independent and dependent variables. Similarly, in order to test the hypotheses of the study, Pearson correlation analysis is conducted by using SPSS software where Type of Social media is the Constant predictor.

\section{RESUlts \& ANALYSIS}

\subsection{Descriptive Analysis}

Descriptive statistics shows the mean and standard deviation of the whole data set. In the table 1, it can be observed that mean and std. deviation value of independent variable i.e. Type of Social Media is 2.66 and 2.70 respectively, which are higher than 1. It shows that large number of companies in Palestine is using different social media e.g. Face book, Twitter, Instagram, YouTube, and Linked In to build relationship with customers and increase their sale and ultimately profitability. On the contrary, mean and std. deviation value of other questions including social media for branding, online marketing, to attract potential customers, traffic to website, engage customers, low cost marketing, product awareness, advertisement campaign, and high rate of return on investment are close to 1 . It shows that there is a normal dispersion of the data.

Table1. Descriptive Statistics

\begin{tabular}{|c|c|c|c|}
\hline \multicolumn{4}{|l|}{ Descriptive Statistics } \\
\hline & Mean & Std. Deviation & $\mathrm{N}$ \\
\hline Type of Social Media & 2.6625 & 2.70463 & 80 \\
\hline Social sharing for network building & .7125 & 1.06965 & 80 \\
\hline social media for branding & .6625 & .84109 & 80 \\
\hline Social media for online marketing & .6625 & .94056 & 80 \\
\hline Social media to attract potential customers & .6500 & .91541 & 80 \\
\hline Social media \& high sales & .8125 & 1.04450 & 80 \\
\hline Social media and traffic to website & .5500 & .76141 & 80 \\
\hline Social media to engage customers & .5875 & .86703 & 80 \\
\hline Social media and low cost marketing & .4375 & .80887 & 80 \\
\hline social media for international marketing & .7375 & 1.17725 & 80 \\
\hline Social media and product awareness & .5125 & .95459 & 80 \\
\hline Social media and advertisement campaign & .5250 & .88554 & 80 \\
\hline Social media \& high rate of return on investment & .5625 & .93921 & 80 \\
\hline Social media to communicate with customers & .5625 & 1.08900 & 80 \\
\hline
\end{tabular}

\subsection{Hypotheses Testing - Correlation Analysis}

\subsubsection{Analysis of Type of Social Media and Customer Relationship Building}

In order to determine the correlation between the dependent and independent variables, two different Pearson correlation tests were conducted wherein first test aimed to determine the correlation between Type of Social media and relationship building with customers. As shown in table 2, type of social media has insignificant correlation with social media for network building $(\mathrm{r}=.010)$, to attract potential customers $(r=.003)$, and to engage customers $(r=.069)$, whereas it has significant positive correlation with social media to communicate with customers $(\mathrm{r}=.104)$. On the other hand, type of social media has insignificant negative correlation with branding (-.062), which indicates that in Palestine, social media is not essentially being incorporated into the marketing strategy of the 
company to achieve the branding purpose. However, positive significant correlation with the communication indicates that social media is used for communication purpose, where customers reach to the companies via social media to inquire about the features and prices of product or services. It also confirms the notion presented by Kim, Lim, \& Brymer (2015) that social media has improved communication between businesses and customers because social media provides companies to connect with customers round the clock while running their campaigns in high visualization. The results also confirm the finding of Hanna, Rohm, \& Crittenden (2011) that concern that through improved and direct communication with customers, businesses are able to build a strong relationship customers. However, the current results have declined the notion that social media is effective source of branding; as the current results suggest that in Palestine social media is not efficiently being used for marketing and branding.

Table2. Correlation Analysis between Type of Social Media and Customer relationship building

\begin{tabular}{|c|c|c|c|c|c|c|c|}
\hline \multicolumn{8}{|l|}{ Correlations } \\
\hline & & $\begin{array}{l}\text { Type of } \\
\text { Social } \\
\text { Media }\end{array}$ & $\begin{array}{l}\text { Social } \\
\text { sharing for } \\
\text { network } \\
\text { building }\end{array}$ & $\begin{array}{l}\text { Social } \\
\text { media } \\
\text { for } \\
\text { branding }\end{array}$ & $\begin{array}{l}\text { Social media } \\
\text { to attract } \\
\text { potential } \\
\text { customers }\end{array}$ & $\begin{array}{l}\text { Social } \\
\text { media to } \\
\text { engage } \\
\text { customers }\end{array}$ & $\begin{array}{l}\text { Social media to } \\
\text { communicate } \\
\text { with customers }\end{array}$ \\
\hline \multirow{3}{*}{$\begin{array}{l}\text { Type of Social } \\
\text { Media }\end{array}$} & Pearson Correlation & 1 & .010 & -.062 & .003 & .069 & .104 \\
\hline & Sig. (2-tailed) & & .931 & .586 & .980 & .541 & .359 \\
\hline & $\mathrm{N}$ & 80 & 80 & 80 & 80 & 80 & 80 \\
\hline \multirow{3}{*}{$\begin{array}{l}\text { Social sharing } \\
\text { for network } \\
\text { building }\end{array}$} & Pearson Correlation & .010 & 1 & .074 & .142 & $.266^{*}$ & .086 \\
\hline & Sig. (2-tailed) & .931 & & .516 & .210 & .017 & .447 \\
\hline & $\mathrm{N}$ & 80 & 80 & 80 & 80 & 80 & 80 \\
\hline \multirow{3}{*}{$\begin{array}{l}\text { Social media } \\
\text { for branding }\end{array}$} & Pearson Correlation & -.062 & .074 & 1 & .025 & .154 & .099 \\
\hline & Sig. (2-tailed) & .586 & .516 & & .822 & .173 & .381 \\
\hline & $\mathrm{N}$ & 80 & 80 & 80 & 80 & 80 & 80 \\
\hline \multirow{3}{*}{$\begin{array}{l}\text { Social media } \\
\text { to attract } \\
\text { potential } \\
\text { customers }\end{array}$} & Pearson Correlation & .003 & .142 & .025 & 1 & $.230^{*}$ & .124 \\
\hline & Sig. (2-tailed) & .980 & .210 & .822 & & .040 & .274 \\
\hline & $\mathrm{N}$ & 80 & 80 & 80 & 80 & 80 & 80 \\
\hline \multirow{3}{*}{$\begin{array}{l}\text { Social media } \\
\text { to engage } \\
\text { customers }\end{array}$} & Pearson Correlation & .069 & $.266^{*}$ & .154 & $.230^{*}$ & 1 & .034 \\
\hline & Sig. (2-tailed) & .541 & .017 & .173 & .040 & & .762 \\
\hline & $\mathrm{N}$ & 80 & 80 & 80 & 80 & 80 & 80 \\
\hline \multirow{3}{*}{$\begin{array}{l}\text { Social media } \\
\text { to communicate } \\
\text { with customers }\end{array}$} & Pearson Correlation & .104 & .086 & .099 & .124 & .034 & 1 \\
\hline & Sig. (2-tailed) & .359 & .447 & .381 & .274 & .762 & \\
\hline & $\mathrm{N}$ & 80 & 80 & 80 & 80 & 80 & 80 \\
\hline \multicolumn{3}{|c|}{$\begin{array}{l}\text { *. Correlation is significant at the } 0.05 \text { level } \\
\text { (2-tailed). }\end{array}$} & & & & & \\
\hline
\end{tabular}

\subsubsection{Analysis of Type of Social Media and Increased Sale Volume}

In order to find the correlation between the type of social media and increase sale volume of the companies in Palestine, Pearson correlation analysis was conducted which included the questions concerning use of social for high sale, for low cost marketing and high rate of return of return on investment of the companies. In the table 3, it can be seen that independent variable i.e. Type of social media has significantly positive correlation with the variables i.e. high sale $(r=.215)$ and high rate of return on investment $(\mathrm{r}=.180)$, whereas there is negative correlation of independent variable with social media and low cost marketing. Significantly positive correlation between the variables indicate that on account of using social media, companies in Palestine have observed high sale as well as high rate of return on investment. On the contrary, negative correlation with low cost marketing indicates that the phenomena that social media is a cheap and low cost marketing tactics is wrong, as companies in Palestine has not observed significant change in their marketing cost as a result of social media. The results confirm the findings of Poynter (2010) that found that by selecting the right social 
media and engaging with customers, businesses can significantly improve their sales. Similarly, Rao \& Raghavendra (2016) had found that social media specifically Facebook is an efficient source of generating leads, which when handled carefully and professionally can be converted into sales. In this regard, instant messaging is regarded the key for interacting and communicating with the customers.

Table3. Correlation analysis between type of social media and high sale

\begin{tabular}{|c|c|c|c|c|c|}
\hline \multicolumn{6}{|c|}{ Correlations } \\
\hline & & $\begin{array}{l}\text { Type of } \\
\text { Social Media }\end{array}$ & $\begin{array}{l}\text { Social media } \\
\& \text { high sales }\end{array}$ & $\begin{array}{l}\text { Social media and } \\
\text { low cost marketing }\end{array}$ & $\begin{array}{l}\text { Social media \& high rate of } \\
\text { return on investment }\end{array}$ \\
\hline \multirow{3}{*}{$\begin{array}{l}\text { Type of } \\
\text { Social } \\
\text { Media }\end{array}$} & Pearson Correlation & 1 & .215 & -.065 & .180 \\
\hline & Sig. (2-tailed) & & .056 & .568 & .109 \\
\hline & $\mathrm{N}$ & 80 & 80 & 80 & 80 \\
\hline \multirow{3}{*}{$\begin{array}{l}\text { Social } \\
\text { media \& } \\
\text { high sales }\end{array}$} & Pearson Correlation & .215 & 1 & -.007 & -.020 \\
\hline & Sig. (2-tailed) & .056 & & .954 & .859 \\
\hline & $\mathrm{N}$ & 80 & 80 & 80 & 80 \\
\hline \multirow{3}{*}{$\begin{array}{l}\text { Social } \\
\text { media and } \\
\text { low cost } \\
\text { marketing }\end{array}$} & Pearson Correlation & -.065 & -.007 & 1 & .122 \\
\hline & Sig. (2-tailed) & .568 & .954 & & .282 \\
\hline & $\mathrm{N}$ & 80 & 80 & 80 & 80 \\
\hline \multirow{3}{*}{$\begin{array}{l}\text { Social } \\
\text { media \& } \\
\text { high rate of } \\
\text { return on } \\
\text { investment }\end{array}$} & Pearson Correlation & .180 & -.020 & .122 & 1 \\
\hline & Sig. (2-tailed) & .109 & .859 & .282 & \\
\hline & $\mathrm{N}$ & 80 & 80 & 80 & 80 \\
\hline
\end{tabular}

\subsubsection{Empirical Analysis}

To further confirm whether or not there is relationship between the identified dependent and independent variables two regression analyses were conducted.

\subsubsection{ANOVA Factor Analysis of Social Media and Customer Relationship Building}

The model estimated in the regression also confirmed a close relationship between the dependent and independent variables of the study. The ANOVA table for the chosen variables has shown that all the explanatory variables were significant in describing the impact of social media on customer relationship building in the business firms of Palestine. The results of R-Square value .023 indicated as $2 \%$ of changes in the dependent variable can be observed through the changes in independent variables. Given that the change is considerably low, the explanatory variables are unable to explain the impact of social media on the customer relationship building. Sig value $=.881$ above the alpha value i.e. 0.05 has confirmed the significant relationship between the variables.

Table4. ANOVA Factor Analysis of Social media and customer relationship building

\begin{tabular}{|l|l|l|l|l|}
\hline \multicolumn{5}{|c|}{ Model Summary } \\
\hline Model & R & R Square & Adjusted R Square & Std. Error of the Estimate \\
\hline 1 & $.152^{\mathrm{a}}$ & .023 & -.043 & 2.76212 \\
\hline
\end{tabular}

\begin{tabular}{|l|l|l|l|l|l|l|}
\hline \multicolumn{2}{|c|}{ ANOVA $^{\text {b }}$} \\
\hline \multirow{2}{|l|}{ Model } & Sum of Squares & df & Mean Square & F & Sig. \\
\hline & Regression & 13.317 & 5 & 2.663 & .349 & $.881^{\text {a }}$ \\
\cline { 2 - 8 } & Residual & 564.571 & 74 & 7.629 & & \\
\cline { 2 - 5 } & Total & 577.887 & 79 & & & \\
\hline
\end{tabular}

The Beta (regression) coefficients (refer to table 5) showed positive impact of social media to engage customers $=.276$ and social media to communicate with customers $=.283$, whereas there is negative relationship with others such as social media for branding $=-.274$, Social sharing for network building $=-.034$, and Social media to attract potential customers $=-.082$. Positive relationship between type of social media and social media to engage customers and communicate with them further confirm that 
social media has been used in the business firms of Palestine to build relationship with customers, however, it also confirms that it has not been using for branding or networking.

Table5. Regression Analysis of social media and customer relationship building

\begin{tabular}{|c|c|c|c|c|c|c|}
\hline \multicolumn{7}{|c|}{ Coefficients $^{\mathrm{a}}$} \\
\hline & & \multicolumn{2}{|c|}{ Unstandardized Coefficients } & \multirow{2}{*}{$\begin{array}{l}\text { Standardized Coefficients } \\
\text { Beta }\end{array}$} & \multirow[b]{2}{*}{$\mathrm{t}$} & \multirow[b]{2}{*}{ Sig. } \\
\hline \multicolumn{2}{|c|}{ Model } & B & Std. Error & & & \\
\hline \multirow[t]{6}{*}{1} & (Constant) & 2.600 & .497 & & 5.232 & .000 \\
\hline & $\begin{array}{l}\text { Social sharing for network } \\
\text { building }\end{array}$ & -.034 & .303 & -.013 & -.112 & .911 \\
\hline & Social media for branding & -.274 & .376 & -.085 & -.728 & 469 \\
\hline & $\begin{array}{l}\text { Social media to attract } \\
\text { potential customers }\end{array}$ & -.082 & .353 & -.028 & -.232 & .817 \\
\hline & $\begin{array}{l}\text { Social media to engage } \\
\text { customers }\end{array}$ & .276 & .384 & .089 & .720 & .474 \\
\hline & $\begin{array}{l}\text { Social media to } \\
\text { communicate with customers }\end{array}$ & .283 & 290 & .114 & .977 & .332 \\
\hline
\end{tabular}

\subsubsection{Regression Analysis of Type of Social Media and High Sale volume}

The ANOVA table 6 shows that all the explanatory variables were significant in describing the impact of social media on high sale volume in the business firms of Palestine. The results of R-Square value .088 indicated as $9 \%$ of changes in the dependent variable can be observed through the changes in independent variables. Given that the change is considerably low, the explanatory variables are unable to explain the impact of social media on the high sale volume. Sig value $=.881$ above the alpha value i.e. 0.05 has confirmed the significant relationship between the variables.

Table6. ANOVA Factor Analysis of Social media and high sale volume

\begin{tabular}{|l|l|l|l|l|}
\hline \multicolumn{2}{|c|}{ Model Summary } \\
\hline Model & R & R Square & Adjusted R Square & $\begin{array}{l}\text { Std. Error of the } \\
\text { Estimate }\end{array}$ \\
\hline 1 & $.296^{\mathrm{a}}$ & .088 & .052 & 2.63377 \\
\hline \multicolumn{5}{|l}{} \\
\hline
\end{tabular}

\begin{tabular}{|l|l|l|l|l|l|l|}
\hline \multicolumn{2}{|c|}{ ANOVA $^{\mathbf{b}}$} & Sig. \\
\hline \multicolumn{2}{|l|}{ Model } & Sum of Squares & df & Mean Square & F & $.071^{\text {a }}$ \\
\hline \multirow{3}{*}{1} & Regression & 50.695 & 3 & 16.898 & 2.436 & \\
\cline { 2 - 7 } & Residual & 527.193 & 76 & 6.937 & & \\
\cline { 2 - 7 } & Total & 577.887 & 79 & & & \\
\hline
\end{tabular}

The Beta (regression) coefficients (refer to table 7) showed positive impact of social media on the high sales $=.565$ and high rate of return to investment $=.563$, whereas there is negative relationship

with others such as social media and low cost marketing $=-.291$. It confirms the findings of Pearson correlation that found positive correlation between social media and high sales and rate of return on investment of companies. However, it rejected the idea that social media is a low cost marketing channel.

\section{DISCUSSION AND CONCLUSION}

The study aimed to find out the impact of social media on the businesses firms in Palestine. For this purpose, the author developed and tested two hypotheses constructed out of one independent and two dependent variables. The findings of the study has confirmed the findings of the previous researches that found the positive relationship between social media and customer relationship building and high sales of the companies. Pearson correlation analysis and regression model estimation showed that companies using social media in Palestine are able to use social media for building relationship with 
customers. In this way, they are getting the benefit from comment and inbox features of social media where customers can easily contact the company to inquire about the products and services or submit their feedback and complaint. These findings of the first hypothesis match with the findings of studies including (Aral, Dellarocas, \& Godes, 2013) (Fue, Li, \& Wenyu, 2009) and (Hanna, Rohm, \& Crittenden, 2011). On the contrary, the findings of the study rejected the idea that Palestinian companies are using social media for branding and networking. A number of studies such as (Kietzmann, Hermkens, McCarthy, \& Silvestre, 2011), (Patrick, 2008) and (Qualman, 2010) have found that businesses through networking and sharing are able to reach to customers. The results of the current study, however, have rejected the idea. This raises further question if companies are not using social media for networking or branding, how they are able to promote their brands. According to Naylor, Lamberton, \& West (2012) one of the significant challenge that today's businesses face concerns with how to get followers to go from looking at a photo to going to their website and buy product or service. For this purpose, it is important to have strong network through a number of followers who share the post of the companies. In the case of Palestinian firms, the results show that they are not networking on the social media, but using it for communication purpose only. It indicates that they are not approaching new and potential customers and have social media for dealing with only existing customers.

The finding of the second hypothesis also confirms and matches with the previous researches that found positive relationship between social media and increase revenue or sale of the company. According to Scott (2017) due to various features of social media, companies are able to increase their sale. He found that social media is an effective source of generating leads and if promoted adequately, leads can be converted into sales. Similarly, Li, Zhou, Kashyap, \& Yang (2008) indicated that social media has recently launched e-commerce features such as Instagram, which has resulted in an ease for customers to make a purchase without going to the website. In the case of Palestinian business firms, the findings confirmed high and increase sale due to social media. However, it is not identified what factors are involved that prompt customers to make a purchase. As identified by Naylor, Lamberton, \& West (2012) there were certain actions that must be taken by companies to ensure that customers prompts to buy the products and services including responsiveness, offers and promotion, informative content, interesting visuals, and exclusive content.

\section{IMPLICATION, LIMITATION AND FUTURE RESEARCH DIRECTION}

Due to certain limitations of the current study, it has not focused on how businesses firms in Palestine are using social media and what particular actions are responsible for the improved customer relationship building and high sales. The current study has served the companies not using social media to get the insight to find how social media is helpful for the firms. Considering the limitations and findings of the study, it is important to conduct further research to identify the ways social media is being used by the Palestinian firms for the businesses.

\section{REFERENCE}

[1] Aral, S., Dellarocas, C., \& Godes, D. (2013). Introduction to the Special Issue-Social Media and Business Transformation: A Framework for Research. Information System Research, 24-1.

[2] Fue, Z., Li, H., \& Wenyu, D. (2009). Social factors in user perceptions and responses to advertising in online social networking communities. Journal of Interactive Advertising, 10, 1, pp. 1-13.

[3] Hanna, R., Rohm, A., \& Crittenden, V. (2011). We're all connected: The power of the social media ecosystem. Business Horizons, 265-273, 54-3.

[4] Jones, N., Borgman, R., \& Ulusoy, E. (2015). Impact of social media on small businesses. Journal of Small Business and Enterprise Development, 22: 4, 611-632.

[5] Kietzmann, J. H., Hermkens, K., McCarthy, I. P., \& Silvestre, B. S. (2011). Building Blocks for Social Media. Business Horizons, Vol. 54, Issue 3, 241-251.

[6] Kim, W. G., Lim, H., \& Brymer, R. (2015). The effectiveness of managing social media on hotel performance. International Journal of Hospitality Management, 165-171, 44.

[7] Konovalova, N., I, K., \& M., K. (2016). CREDIT RISK MANAGEMENT IN COMMERCIAL BANKS. POLISH JOURNAL OF MANAGEMENT STUDIES, 13(2), 90-100.

[8] Kotler, P., Kartajaya, H., \& Setiawan, I. (2016). Marketing 4.0: Moving from Traditional to Digital. John Wiley \& Sons. 
[9] Li, F., Zhou, N., Kashyap, R., \& Yang, Z. (2008). Brand trust as a second-order factor: an alternative measurement model. International Journal of Market Research, 50, 6, pp. 817.

[10] Liang, T., Ho, P., Li, T., \& Turban, E. (2011). What drives social commerce: the role of social support and relationship quality. International Journal of Electronic Commerce, 16, 2, pp. 69-90.

[11] Lu, Y., Zhao, L., \& Wang, B. (2010). From virtual community members to c2c e-commerce buyers: trust in virtual communities and its effect on consumers' purchase intention. . Electronic Commerce Research \& Applications, , 9, 4, pp. 346-360.

[12] Naylor, R., Lamberton, C., \& West, P. (2012). Beyond the 'like' button: the impact of mere virtual presence on brand evaluations and purchase intentions in social media settings. journal of Marketing, 76, 6, pp. 105-120.

[13] Patrick, F. (2008). Exploring the Role of Social Media in Transnational Advocacy. IGI Global.

[14] Poynter, R. (2010). The Handbook of Online and Social Media Research: Tools and Techniques for Market Researchers. John Wiley \& Sons.

[15] Qualman, E. (2010). Socialnomics: How Social Media Transforms the Way We Live and Do Business. John Wiley \& Sons.

[16] Rao, \& Raghavendra, N. (2016). Social Media Listening and Monitoring for Business Applications. IGI Global.

[17] Scott, D. M. (2017). The New Rules of Marketing and PR: How to Use Social Media, Online Video, Mobile Applications, Blogs, Newsjacking, and Viral Marketing to Reach Buyers Directly. John Wiley \& Sons

\section{AUTHORS' BIOGRAPHY}

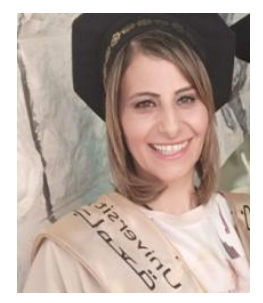

Nermeen Sayyad, Faculty of Business and Economics, Department of Administration and Marketing, AL-Quds University, Palestine

Citation: Nermeen Sayyad. Importance of Social Media in Business Firm in Palestine \& its Effect. International Journal of Managerial Studies and Research (IJMSR), vol 6, no. 10, 2018, pp. 46-54. doi:http://dx.doi.org/10.20431/2349-0349.0601004.

Copyright: (C) 2018 Authors. This is an open-access article distributed under the terms of the Creative Commons Attribution License, which permits unrestricted use, distribution, and reproduction in any medium, provided the original author and source are credited. 